Брохун Н.С., Новіченко Л. С.

\title{
ОБЛІКОВО-АНАЛІТИЧНЕ ЗАБЕЗПЕЧЕННЯ УПРАВЛІННЯ ПІДПРИЄМСТВОМ: ТЕОРЕТИЧНЕ ОСМИСЛЕННЯ ЕКОНОМІЧНОГО ЗМICTУ
}

\begin{abstract}
Досліджено теоретичні передумови створення обліково-аналітичного забезпечення як ключового елементу забезпечення фінансової стійкості та передумови довгострокового функціонування підприсмства. На основі аналізу трактувань поняття “обліково-аналітичне забезпечення” в різних літературних джерелах систематизовані основні підходи до пояснення його змісту. Акцентовано увагу на багатоаспектності трактування економічного змісту досліджуваного терміну. На основі критичного аналізу систематизованих підходів обгрунтовано та запропоновано комплексний підхід до визначення економічного змісту поняття “обліково-аналітичне забезпечення”. Запропоновані принциии організації обліково-аналітичного забезпечення управління підприємством в сучасних умовах господарювання.
\end{abstract}

Ключові слова: обліково-аналітичне забезпечення, інформаџійний потік, релевантна інформація, система управління, фінансова стійкість, ризики, оцінка ефективності.

Постановка проблеми. Економічна нестабільність умов функціонування вітчизняних підприємств, негативна динаміка зростання фінансових ризиків, глобальний розвиток конкуренції, стрімке розширення та впровадження в практичну діяльність інформаційно-комп'ютерних технологій призводить до модифікації підходів управління суб' єктами господарювання. Зміни економічного середовища функціонування зумовлюють пошук нових напрямів та інструментів управління діяльністю 3 метою забезпечення безперервного та сталого розвитку підприємства.

Система управління підприємством знаходиться в прямій залежності від якісного та оперативного формування інформаційного базису для прийняття кваліфікованих та дієвих управлінських рішень. На даний момент часу склалась ситуація, коли концептуальні основи бухгалтерського обліку частково задовольняють інформаційні вимоги управлінського персоналу. Виникає нагальна потреба у розширенні та забезпеченні детальної аналітичності інформації, ii структуризації 3 урахуванням ризиків діяльності. Тому на сьогодні актуальною $\epsilon$ проблема створення обліково-аналітичного забезпечення як ключового елементу забезпечення фінансової стійкості та передумови довгострокового функціонування підприємства.

(C) Брохун Наталія Степанівна, к.е.н, доцент, доцент кафедри обліку i аудиту, ДВНЗ "Ужгородський національний університет”, м. Ужгород, тел.: +380509475924, e-mail: nataliya.brokhun@uzhnu.edu.ua Новіченко Людмила Степанівна, к.е.н., доцент, доцент кафедри аудиту, Національна академія статистики, обліку та аудиту, м. Київ, тел.: +380674560111, e-mail: novichenko2104@gmail.com
Аналіз останніх досліджень і публікацій. Дослідженню проблемних питань обліково-аналітичного забезпечення управління суб'єктами господарювання, визначенню його сутності й складових присвятили свої праці такі вчені та науковці, як: С.П. Барановська, І.А. Бланк, О.М. Брадул, Р.Ф. Бруханський, О.В. Вакун, В.О. Волощук, В.В. Вольська, О.Д. Гудзинський, Т.А. Гоголь, Н.В. Голячук, В.М. Жук, А.Г. Загородній, Т.Г. Камінська, М.Д. Корінько, О.А. Кравченко, М.Д. Крамчанінова, С.В. Мних, Т.М. Пахомова, А.А. Пилипенко, М.С. Пушкар, І.Б. Садовська, Я.В. Соколов, В.В. Смирнова, Л.В. Усатова, А.М. Штангерет та ін.

Разом $з$ тим, більша частина науковців у своїх працях акцентує увагу на визначенні особливостей формування обліково-аналітичного забезпечення в різних предметних галузях дослідження, вивчають співвідношення та ототожнення терміну “обліково-аналітичне забезпечення" 3 суміжними поняттями (“обліково-аналітична система", обліковоінформаційне забезпечення”, “інформаційне забезпечення" та інші). У зв'язку 3 цим, потребують подальших досліджень питання систематизації підходів до трактування економічного змісту поняття "обліковоаналітичне забезпечення" та визначення шляхів розвитку теоретичних основ організації облікового аналітичного забезпечення на підприємстві.

Формулювання цілей статті. Метою дослідження $\epsilon$ поглиблення теоретичних основ та здійснення наукового обгрунтування економічного змісту поняття "обліковоаналітичне забезпечення". 
Опис основного матеріалу дослідження. Висока залежність суб'єктів господарювання від коливань ринкової кон'юнктури та ризиків діяльності вимагають від управлінської ланки швидкого реагування на відповідні зміни. В такій ситуації пріоритетного значення в системі управління підприємства набуває побудова дієвого механізму керування інформаційними потоками, розробка заходів 3 мінімізації ризиків, пов'язаних 3 наданням недостовірної облікової інформації. Забезпечення взаємодії між структурними підрозділами підприємства та раціональне управління інформаційними потоками базуються на організації відповідного обліково-аналітичного забезпечення.

Формування принципів побудови ефективного обліково-аналітичного забезпечення управління підприємством передбачає наявність термінологічної єдності та теоретичного обгрунтування сутності поняття “обліковоаналітичне забезпечення". Чітка інтерпретація змісту зазначеного поняття ускладнюється відсутністю методологічної єдності в його трактуванні в науковому доробку науковців.

"На сьогодні в науковій літературі не сформовано загального розуміння сутності поняття «обліково-аналітичне забезпечення» системи управління, що призводить до виникнення значної кількості підходів, що в цілому не дозволяє сформувати загальну модель побудови системи інформаційної підтримки менеджменту на базі використання обліковоаналітичної системи підприємства" [2, с. 210].

Дослідження сутності поняття "обліковоаналітичне забезпечення" показало, що серед теоретиків відсутня єдина точка зору щодо його трактування. Вакун О.В. вважає, що “однією 3 основних причин відсутності однозначності щодо трактування даного поняття $є$ його відсутність у міжнародній обліковій практиці, зокрема дане поняття не використовується представниками англо-американської облікової школи, а подібні дослідження відносяться до сфери управлінського обліку або обліку в управлінні" [2, c. 211].

Іншу причину у наявності двозначності трактування терміну “обліково-аналітичне забезпечення" вбачає В.Ф. Яценко. Так, автор зазначає, що "міждисциплінарний характер дослідження сутнісного наповнення категорії "забезпечення" у поєднанні із різноманітністю принципів і методологічних підходів, технологій та інструментів управління підприємством обумовлюють невизначеність самої дефініції «обліково-аналітичне забезпечення» [16, с. 76]. Вважаємо, що слід доповнити наведений перелік причин також наступними: використання слів- синонімів; застосування різних назв тотожних термінів; наявність міждисциплінарних зв'язків та їх ігнорування при визначення змісту економічних понять.

Узагальнивши погляди окремих науковців щодо розкриття сутності поняття "обліковоаналітичне забезпечення”, можна виділити наступні підходи:

1. Системний підхід - єдність підсистем обліку, аудиту та аналізу, що взаємодіють через інформаційні потоки.

Прихильником даного підходу в частині визначення змісту поняття “обліково-аналітичне забезпечення" є Л.О. Волощук, який вважає, що "обліково-аналітичне забезпечення - це єдність підсистем обліку, аудиту та аналізу, що взаємодіють через інформаційні потоки в процесі формування й передачі оперативної та якісної обліково-аналітичної інформації для забезпечення обгрунтованості й ефективності прийняття управлінських рішень у системі управління підприємством, а також зовнішніми користувачами" [3, с. 330]. Тотожне теоретичне обгрунтування змісту даного терміну наведено в статті П.Р. Пуцентейло [10].

3 ними також погоджується I.В. Зенькіна, яка зазначає, що “обліково-аналітичне забезпечення - це інтегрована система обліку та аналізу, що систематизує інформацію для обгрунтування бізнес-стратегії, координації напрямів перспективного розвитку підприємства, системної оцінки ефективності реалізації оперативно-тактичних та стратегічних управлінських рішень" [6, с. 1].

Побережець О.В., Макаревич Г.В. "під обліково-аналітичним забезпеченням управління підприємства розуміють систему накопичення, узагальнення та передачі інформації, яка допомагає управлінцям відповідного рівня приймати рішення, здійснювати планування та контролювати діяльність суб'єкта господарювання у сучасних умовах" [9, с. 59].

2. Процесний підхід - організація процесу збору, обробки, узагальнення i збереження обліково-аналітичної інформації.

Представники даного підходу визначають зміст поняття "обліково-аналітичне забезпечення" як "процес підготовки обліково-аналітичної інформації, забезпечення іiі кількості та якості. Таким чином, поняття обліково-аналітичного забезпечення постає у двох значеннях:

а) діяльність, пов'язана зі збором, реєстрацією, узагальненням, збереженням, передачею та аналітичним опрацюванням інформації;

б) забезпечення системи управління відповідною кількістю необхідної якісної інформації" [8, с. 192-193]. 
Аналогічне трактування сутності поняття "обліково-аналітичне забезпечення" наводять у свої працях Т.М. Безродна [1], В.В. Вольська [4, c. 87], Т.А. Гологоль [5, с. 41], Л.Ю. Шевців, А.Б. Шевців $[13$, с. 34$]$, які вважають, що “обліково-аналітичне забезпечення” - це організація процесу збору, обробки, узагальнення i збереження облікової та аналітичної інформації, узгодження іiі руху між різними структурними підрозділами управлінської служби, забезпечення ефективної взаємодії із зовнішнім середовищем 3 метою інформаційного забезпечення системи управління та зовнішніх користувачів.

3. Синтез облікових та аналітичних операцій формування обліково-аналітичної системи.

Окремими авторами (М.В. Реслер [11], Р.П. Юзва [15]) термін “обліково-аналітичне забезпечення" пояснюється як “сукупність облікових і аналітичних процесів, об'єднаних у обліково-аналітичну систему та спрямованих на задоволення інформаційних потреб користувачів шляхом перетворення первинної інформації в узагальнюючу згідно з визначеними цілями, а також нормативно-правовим, методичним, організаційним, програмним, математичним, технічним та ергономічним забезпеченнями".

Представники даного підходу виокремлюють "систему обліково-аналітичного забезпечення управління підприємством, яка $\epsilon$ синтезом облікової та аналітичної підсистем, основною перевагою виділення якої $\epsilon$ налагоджена взаємодія задля досягнення синергетичного ефекту. Результатом функціонування такої системи $€$ генерування обліково-аналітичної інформації - сукупності відомостей та даних обліково-аналітичного характеру, що можуть використовуватись у процесі прийняття управлінських рішень на різних рівнях системи управління" [2, с. 212].

4. Компонент інформаційного забезпечення формування інформаційних потоків.

Представники даного підходу (Т.Г. Камінська [7], С.В. Сирцева [12], А.М. Штангерет [14, с. 135]) наводять скорочене трактування терміну "обліково-аналітичне забезпечення", яке “містить інформацію, яку надає бухгалтерський облік, а також інформацію, створювану 3 застосуванням методів економічного аналізу". В даному випадку обліково-аналітичне забезпечення зводиться лише до формування обліково-аналітичної інформації, яка надається для потреб управлінського персоналу.

5. Інтегрований підхід - сукупність різних видів інформації та обліково-аналітичних процедур.

Вакун О.В. пропонує використовувати інтегрований підхід до розуміння сутності поняття “обліково-аналітичне забезпечення”, що передбачає його розгляд як сукупність різних видів обліково-аналітичної інформації, що утворюється в результаті функціонування обліково-аналітичної системи підприємства, так і процес функціонування даних систем, що складається із набору відповідних обліковоаналітичних процедур [2, с. 213].

Узагальнюючи всі вищенаведені підходи до визначення економічного змісту поняття “обліково-аналітичне забезпечення" можна зробити висновок, що даний термін $\epsilon$ багатоаспектним. 3 метою наукового обгрунтування економічного змісту поняття “обліково-аналітичне забезпечення" вважаємо за доцільне систематизувати принципи його організації (табл. 1).

\section{Таблиця 1}

Принципи організації обліково-аналітичного забезпечення підприсмства

\begin{tabular}{|l|l|l|}
\hline $\begin{array}{c}\text { № } \\
\text { 3/п }\end{array}$ & Назва принципу & \multicolumn{1}{|c|}{ Характеристика } \\
\hline 1 & Синергї & $\begin{array}{l}\text { Переваги, які отримує підприємство від вдалого поєднання обліково-аналітичної } \\
\text { інформації, коли загальний ефект перевищує суму ефектів потенціалу цих } \\
\text { елементів }\end{array}$ \\
\hline 2 & Емерджентності & $\begin{array}{l}\text { Завдяки взаємодії й поєднанню різних видів обліку та аналізу для досягнення } \\
\text { єдної мети забезпечується формулювання обгрунтованої, якісної, достовірної й } \\
\text { комплексної обліково-аналітичної інформації }\end{array}$ \\
\hline 3 & Комплексності & $\begin{array}{l}\text { Реалізується через взаємодію інформаційних потоків бухгалтерського обліку й } \\
\text { інформації, яка формується за допомогоюметодів аналізу }\end{array}$ \\
\hline 4 & $\begin{array}{l}\text { Безперервності } \\
\text { взаємодії }\end{array}$ & $\begin{array}{l}\text { Взємозв’язок між системою бухгалтерського обліку та аналізу на підприємстві } \\
\text { упвинен бути безперервним з метою надання релевантної інформації для } \\
\text { упрання на різних рівнях }\end{array}$ \\
\hline 5 & Ефективності & $\begin{array}{l}\text { Затрати, понесені у процесі розробки, здійснення та впровадження обліково- } \\
\text { аналітичного забезпечення повинні бути нижчими, ніж ефект, отриманий від } \\
\text { прийняття управлінських рішень на основі отриманоїінформації }\end{array}$ \\
\hline
\end{tabular}




\begin{tabular}{|c|c|}
\hline \\
\hline управління & агатоаспектністю та необхідністю новог \\
\hline повинна базувати на & сутнісного наповнення зазначеного терміну. \\
\hline в таблиці 1 & Проаналізувавши х характеристики даног \\
\hline $\begin{array}{lll}\text { використання } & \text { забезпечить } & \text { відповідність } \\
\text { обліково-аналітичного } & \text { забезпечення }\end{array}$ & $\begin{array}{ll}\text { поняття та існуючі підходи до його трактування } \\
\text { запропоновано }\end{array}$ \\
\hline $\begin{array}{l}\text { собливостям } \quad \text { здійснення } \\
\text { iяльності підприємства. }\end{array}$ & $\begin{array}{l}\text { економічного змісту поняття: “обліково- } \\
\text { аналітичне забезпечення”- - це система обліково- }\end{array}$ \\
\hline ховуючи виокремленні підходи до & аналітичної інформації та інформац \\
\hline & \\
\hline & $\begin{array}{l}\text { реєстрації, узагальнення, зберех } \\
\text { аналітичної обробки та п1 }\end{array}$ \\
\hline парату не мають повної система & тості функціонування ці. \\
\hline ніфікації наукової теорії, п & \\
\hline азначеного поняття. Так & ר \\
\hline обліково-аналітичне забезпечення" & йних потоків в $\mathrm{p}$ \\
\hline озуміти систему обліково- & ених користувачів, нейтралізація в \\
\hline нформації та інформаційних пото & внутрішніх та зовнішніх загроз ро \\
\hline нення, збереження, передачі, ан & $\begin{array}{l}\text { підприємства, } 3 \mathrm{HI} \\
\text { ризику в цілому нел }\end{array}$ \\
\hline & \\
\hline ллісної інформаційн & забез \\
\hline стві. & ктивами \\
\hline Вис & \\
\hline & \\
\hline & \\
\hline & \\
\hline
\end{tabular}
“обліково-аналітичне забезпечення" як

\section{СПИСОК ВИКОРИСТАНИХ ДЖЕРЕЛ}

1. Безродна Т.М. Обліково-аналітичне забезпечення управління підприємством: визначення сутності поняття [Електроннй ресурс] T.M. Безродна. - Режим доступу: http://dspace.snu.edu.ua:8080/jspui/bitstream/123456789/523/8/bezrodna.pdf.

2. Вакун О.В. Економічна сутність обліково-аналітичного забезпечення системи управління підприємством / О.В. Вакун // Вісник ОНУ ім. І.І. Мечникова. - 2016. - Т. 21. - Вип. 1. - С. 210-213.

3. Волощук Л.О. Обліково-аналітичне забезпечення управління інноваційним розвитком підприємства / Л.О. Волощук // Праці Одеського політехнічного університету. - 2011. - Вип. 2 (36). - С. 329-334.

4. Вольська В.В. Методичні підходи до обліково-аналітичного забезпечення та аудиту управлінської діяльності аграрних підприємств / В.В. Вольська // Проблеми теорії та методології бухгалтерського обліку, контролю і аналізу. - 2012. - № 3 (24). - С. 83-88.

5. Гоголь Т.А. Обліково-аналітичне забезпечення управління підприємств малого бізнесу : [монографія] / Т.А. Гоголь. - Чернігів : Видавець Лозовий В.М., 2014. - 384 с.

6. Зенькина И.В. Учетно-аналитическое обеспечение стратегического управления коммерческой организацией / И.В. Зенькина // Аудит и финансовый анализ. - 2009. - №2. - С. 1-3.

7. Камінська Т.Г. Обліково-аналітичне забезпечення фінансового менеджменту в сільськогосподарських підприємствах : автореф. дис. ... канд. екон. наук : 08.06 .04 / Т.Г. Камінська; Нац. аграр. ун-т. - К. - $2006 .-20$ с.

8. Касич А.О. Науково-методичні основи обліково-аналітичного забезпечення управління прибутком підприємства / А.О. Касич, Р.М. Циган, О.І. Карбан // Проблеми економіки. - 2013. - № 1. - С. 191-196.

9. Побережець О.В. Обліково-аналітичне забезпечення процесу управління результатами діяльності підприємства / О.В. Побережець, Г.В. Макаревич // ЕКОНОМІКА. ФІНАНСИ. ПРАВО. - 2017. - № 2/2. - С. 5861.

10. Пуцентейло П.Р. Аналітичне забезпечення діяльності підприємства / П.Р. Пуцентейло // Сталий розвиток економіки. - 2015. - № 1. - С. 168-174.

11. Реслер М.В. Системний підхід у поєднанні облікового і аналітичного процесів в управлінні підприємством / М.В. Реслер // Бухгалтерський облік, економічний аналіз та контроль в умовах формування і розвитку сучасних концепцій управління : тези виступів XII Міжнар. наукової конференції ЖДТУ. - Житомир: ЖДТУ, 2013. - С. 158-160. 
12. Сирцева С.В. Методичні підходи до формування обліково-аналітичного забезпечення системи управління аграрними підприємствами / С.В. Сирцева // Вісник аграрної науки Причорномор'я. - 2015. Вип. 2. Том 1. - С. 85-93.

13. Шевців Л.Ю. Обліково-аналітичне забезпечення логістично зорієнтованого стратегічного розвитку підприємства / Л.Ю. Шевців, А.Б. Шевців // Технологический аудит и резервы производства. - 2015. № 6/5(26). - С. 32-38.

14. Штангрет А.М. Процес здійснення обліково-аналітичного забезпечення управління економічною безпекою підприємства / А.М. Штангерет // Наукові записки. - 2015. - № 2 (51). - С. 133-139.

15. Юзва Р.П. Обліково-аналітичне забезпечення управління діяльністю підприємств спиртової промисловості: автореф. дис. канд. екон. наук: 08.00.09 / Р.П.Юзва ; Терноп. нац. екон. ун-т. -Т., $2011 .-20$ с.

16. Яценко В.Ф. Теоретико-методологічний генезис сутності та змісту обліково-аналітичного забезпечення управління підприємством / В.Ф. Яценко // Вісник ЖДТУ. - 2013. - № 3 (65). - С. 75-83.

\section{REFERENCES}

1. Bezrodna T.M. Oblikovo-analitychne zabezpechennia upravlinnia pidpryiemstvom: vyznachennia sutnosti poniattia [Accounting and analytical support for enterprise management: definition of the essence of the concept]. snи.еdи.иа. Retrived from: http://dspace.snu.edu.ua:8080/jspui/bitstream/123456789/523/8/bezrodna.pdf. [in Ukrainian].

2. Vakun O.V. (2016) Ekonomichna sutnist oblikovo-analitychnoho zabezpechennia systemy upravlinnia pidpryiemstvom [The economic essence of the accounting and analytical support of the enterprise management system] / // Visnyk ONU im. I.I. Mechnykova. Bulletin of the ONU them. I.I. Mechnikov, 21(1), 210-213 - 2016. [in Ukrainian].

3. Voloshchuk L.O. (2011) Oblikovo-analitychne zabezpechennia upravlinnia innovatsiinym rozvytkom pidpryiemstva [Accounting and analytical support for the management of innovative development of the enterprise] Pratsi Odeskoho politekhnichnoho universytetu. Labor of Odessa Polytechnic University. 2(36), 329-334- 2011. [in Ukrainian].

4. Volska V.V. (2012) Metodychni pidkhody do oblikovo-analitychnoho zabezpechennia ta audytu upravlinskoi diialnosti ahrarnykh pidpryiemstv [Methodical approaches to accounting and analytical support and audit of management activity of agrarian enterprises]. Problemy teorii ta metodolohii bukhhalterskoho obliku, kontroliu $i$ analizu - Problems of the theory and methodology of accounting, control and analysis, 3(24), 83-88- 2012. [in Ukrainian].

5. Hohol T.A. (2014) Oblikovo-analitychne zabezpechennia upravlinnia pidpryiemstv maloho biznesu [Accounting and analytical support for the management of small businesses] - Chernihiv: Vydavets Lozovyi V.M. [in Ukrainian].

6. Zenkyna Y.V. (2009) Uchetno-analytycheskoe obespechenye stratehycheskoho upravlenyia kommercheskoi orhanyzatsyei [Accounting and analytical support of strategic management of a commercial organization] Audyt y fynansovыi analyz- Audit and financial analysis, 2, 1-3- 2009. [in Ukrainian].

7. Kaminska T.H. (2006) Oblikovo-analitychne zabezpechennia finansovoho menedzhmentu v silskohospodarskykh pidpryiemstvakh [Accounting and analytical support of financial management in agricultural enterprises]. Extended abstract of candidates thesis. Kiev: NAUU [in Ukrainian].

8. Kasych A.O., Tsyhan R.M., Karban O.I. (2013) Naukovo-metodychni osnovy oblikovo-analitychnoho zabezpechennia upravlinnia prybutkom pidpryiemstva [Scientific and methodical foundations of accounting and analytical support for management of enterprise profits]. Problemy ekonomiky-Problems of the economy, 1,191-196 [in Ukrainian].

9. Poberezhets O.V. (2017) Oblikovo-analitychne zabezpechennia protsesu upravlinnia rezultatamy diialnosti pidpryiemstva [Accounting and analytical support for the process of managing the results of the enterprise]. Ekonomika. Finansy. Pravo Economy. Finances. Low,2/2, 58-61-2017 [in Ukrainian].

10. Putsenteilo P.R. (2015) Analitychne zabezpechennia diialnosti pidpryiemstva [Analytical support of the enterprise activity] Stalyi rozvytok ekonomiky- Sustainable development of the economy,1, 168-174- 2015 [in Ukrainian].

11. Resler M.V. (2013) Systemnyi pidkhid u poiednanni oblikovoho i analitychnoho protsesiv v upravlinni pidpryiemstvom [System approach in combination of accounting and analytical processes in the management of the enterprise]. Bukhhalterskyi oblik, ekonomichnyi analiz ta kontrol $\mathrm{v}$ umovakh formuvannia i rozvytku suchasnykh kontseptsii upravlinnia : tezy vystupiv KhII Mizhnar. naukovoi konferentsii ZhDTU - Accounting, economic analysis and control in the conditions of formation and development of modern management concepts: theses of speeches of the XII International Scientific conference of ZhSTU.(pp.158-160). Zhytomyr. [in Ukrainian].

12. Syrtseva S.V. (2015) Metodychni pidkhody do formuvannia oblikovo-analitychnoho zabezpechennia systemy upravlinnia ahrarnymy pidpryiemstvamy [Methodical approaches to the formation of accounting and analytical support for the management system of agrarian enterprises]. Visnyk ahrarnoi nauky Prychornomor'ia - Bulletin of the Agrarian Science of the Black Sea Region,2(1), 85-93-2015. [in Ukrainian].

13. Shevtsiv L.Yu., Shevtsiv A.B. (2015) Oblikovo-analitychne zabezpechennia lohistychno zoriientovanoho stratehichnoho rozvytku pidpryiemstva [Accounting and analytical support of logistic oriented strategic development of the enterprise]. Tekhnolohycheskyi audyt y rezervbl proyzvodstva- Technological audit and production reserves,6/5(26),32-38-2015. [in Ukrainian]. 
14. Shtanhret A.M. (2015) Protses zdiisnennia oblikovo-analitychnoho zabezpechennia upravlinnia ekonomichnoiu bezpekoiu pidpryiemstva [The process of carrying out accounting and analytical support for managing the economic security of the enterprise]. Naukovi zapysky-Proceedings, 2(51), 131-139 -2015. [in Ukrainian].

15. Yuzva R.P. (2011) Oblikovo-analitychne zabezpechennia upravlinnia diialnistiu pidpryiemstv spyrtovoi promyslovosti [Accounting and analytical support for the management of the alcohol industry]. Extended abstract of candidates thesis. Ternopil: TNEU. [in Ukrainian].

16. Yatsenko V.F. (2013) Teoretyko-metodolohichnyi henezys sutnosti ta zmistu oblikovo-analitychnoho zabezpechennia upravlinnia pidpryiemstvom [Theoretical and methodological genesis of the essence and content of accounting and analytical support of enterprise management]. Visnyk ZhDTU-Bulletin ZhSNU, 3(65), 75-83- 2013. [in Ukrainian].

Одержано 15.09.2017 p. 